\title{
Modulation of Ku70/80, Clusterin/ApoJ Isoforms and Bax Expression in Indocyanine-Green- Mediated Photo-Oxidative Cell Damage
}

\author{
Federico Ricci $^{\mathrm{a}}$ Sabina Pucci ${ }^{\mathrm{b}}$ Fabiola Sesti ${ }^{\mathrm{b}}$ Filippo Missiroli ${ }^{\mathrm{a}}$ \\ Luciano Cerulli $^{\mathrm{a}}$ Luigi Giusto Spagnoli ${ }^{\mathrm{b}}$ \\ aSection of Ophthalmology, b Department of Biopathology, University of Rome Tor Vergata, Rome, Italy
}

C. S. Karger AG, Basel

PROOF Copy for personal use only

ANY DISTRIBUTION OF THIS ARTICLE WITHOUT WRITTEN CONSENT FROM S. KARGER AG, BASEL IS A VIOLATION OF THE COPYRIGHT.

\section{Key Words}

Retinal pigmented epithelium • Indocyanine green •

Diode laser - Photodynamic therapy - Bax - DNA repair • Clusterin/ApoJ

\begin{abstract}
Purpose: In order to characterize the biological effects and molecular mechanism underlying indocyanine-green (ICG)mediated photo-oxidative cell damage, human cultured retinal pigmented epithelium (RPE) cells preloaded with ICG were exposed to 810-nm laser irradiation. Cell viability and death induction were examined, as well as the modulation of proteins involved in cell death and DNA repair. Methods: ARPE-19 cells preloaded with $100 \mu \mathrm{M}$ ICG were irradiated using continuous and micropulsed 810-nm laser for the dye photoactivation, and cell viability and apoptosis were evaluated. The expression and subcellular localization of Bax, Ku70, Ku80 and clusterin/ApoJ were analyzed by immunocytochemistry and Western blot. Results: ICG photoactivation induced apoptosis in RPE cells. The micropulsed laser irradiation induced a higher percentage of cell killing as compared to continuous wave. Cell killing was inhibited by so-
\end{abstract}

F.R. and S.P. contributed equally to the work. dium azide, suggesting the involvement of reactive oxygen species in the laser-induced cell damage. Bax was strongly induced after 4 and up to $24 \mathrm{~h}$ of treatment. The nuclear proapoptotic isoform of clusterin/ApoJ was selectively upregulated after $24 \mathrm{~h}$ of treatment. The DNA repair machinery was upregulated after 4 and up to $24 \mathrm{~h}$. Conclusion: These data elucidate some molecular mechanisms involved in cell death induced by ICG photosensitization. The increase and relocalization of Bax into the mitochondria and the upregulation and translocation of the proapoptotic isoform of clusterin/ ApoJ in the nucleus demonstrated the involvement of these proteins in the photo-oxidative cell death pathway. These data point out new molecular targets and suggest potential applications in the therapy of the retinal diseases that could benefit by selective RPE treatment.

Copyright $\odot 2007$ S. Karger AG, Basel

\section{Introduction}

Retinal laser photocoagulation is a treatment which produces therapeutically useful lesions by means of localized temperature elevation initiating at the retinal pigment epithelium layer (RPE), widely employed for several macular diseases. The efficacy of this treatment has been demonstrated in diabetic retinopathy with clinical-

\footnotetext{
Sabina Pucci

Viale Oxford 81

IT-00133 Rome (Italy)

Tel. +39062090 3953, Fax +390620902209

E-Mail sabina.pucci@uniroma2.it
} 
ly significant macular edema [1-3]. The therapeutic effect of laser treatment for these diseases seems to be mediated by a laser-induced photothermal damage to the RPE and by the subsequent defective repair due to surrounding cell proliferation [4-6]. Argon, krypton and more recently 810 -nm diode lasers have been shown to produce therapeutically useful photothermal lesions that have similar histological features in human and animal eyes, and that induce similar effects in the outer retina and RPE layers [7-9]. The mechanism of action of laser photocoagulation is still poorly understood. It has been suggested that RPE cell proliferation may enhance the pump mechanism which produces the clinical effects of reducing subretinal fluid and improving macular pathology $[10,11]$. A different hypothesis suggests that the clinical benefits may derive from the modulation of tissue factors induced by RPE cell wound healing response to the thermal injury $[12,13]$. These changes in the expression of tissue factors could not be induced by dead RPE cells directly affected by the laser burn but would most likely be initiated by nonlethally injured and still viable cells surrounding the area of photocoagulation necrosis [14]. Subthreshold micropulse diode laser photocoagulation with no visible end point has recently been proposed to reduce the chorioretinal thermal elevation and to confine it in accordance with the principles of selective photothermolysis [15] with the goal of a selective RPE treatment capable of minimizing the iatrogenic collateral damage to inner retina layers [16]. Early histological studies have indicated that with subthreshold application of $810-\mathrm{nm}$ infrared laser micropulses, the RPE is almost solely affected. Further studies were unable to identify affected RPE cells adjacent to unaffected retinal outer segments, suggesting that when the laser energy is adequate to affect the RPE cells with thermal injuries, also the adjacent sensory retina sustains some level of damage [17]. Moreover, the heat effect was observed by Desmettre et al. [18] after the induction of hyperthermia in rabbit choroid by means of $810-\mathrm{nm}$ continuous-wave (CW) laser irradiation. They demonstrated the HSP70 overexpression $24 \mathrm{~h}$ after irradiation. To obtain the temperature rise in the selected target, the authors employed a level of energy from 400 to $550 \mathrm{~J} / \mathrm{cm}^{2}$.

An ideal alternative and potentially more selective approach to conventional laser thermal treatment could be the selective photo-oxidative killing of RPE induced by indocyanine green (ICG) photoactivation with $810-\mathrm{nm}$ infrared laser energy. ICG phototoxicity has been effectively shown in different cell systems, and numerous studies have demonstrated that irradiation of ICG- stained cells with near infrared laser $(800-810 \mathrm{~nm})$ induces cell death [19-22]. Probably, the cell killing is mediated by a type 2 photo-oxidative reaction and does not involve thermal damage to cellular ultrastructure, as revealed by electronic microscopy $[19,20]$, although the molecular mechanisms involved in this process are to be clarified.

The aim of this report is to evaluate the possibility of inducing nonthermal damage to human cultured RPE cells by means of a combination of ICG staining and low fluence 810 -nm laser irradiation. Furthermore, we characterized some biological effects and molecular mechanisms underlying ICG-mediated photo-oxidative cell damage induced by micropulsed irradiation in the ARPE19 cell line. To this purpose, we studied the DNA repair machinery activation induced by ICG photoactivation at $810 \mathrm{~nm}$. To define the nature of cell damage, the activation of Ku70 and Ku80 heterodimer subunits was observed because their expression is involved in the regulation of cell death induction and inhibited by heat shock [23-25]. Moreover, the activation of the proapoptotic pathway after damage induced by ICG photosensitization at $810 \mathrm{~nm}$ was observed. Recently the physical interaction among Ku70, DNA repair protein, clusterin/ApoJ and Bax in the cytoplasmic compartment was observed in UVC-irradiated cells as a control mechanism of cell death induction [26]. Therefore, we observed the expression and the subcellular relocalization of these proteins after ICG-mediated photoxidative damage. Several papers focused on the role of the different clusterin/ApoJ isoforms in apoptosis induction [27]. The pattern shift of the different isoforms appears strictly linked to different biological functions. The preferential expression of the proapoptotic nuclear form induced by UV irradiation or oxidative damage irradiation is correlated to Ku70 activation and Bax relocalization to mitochondria. The interaction of nuclear clusterin with Ku70 subunit in the cytoplasm was demonstrated to play an essential role in apoptosis induction inhibiting DNA repair. Therefore, in the present paper we observed the effect of ICG-mediated laser irradiation on cell viability and on the expression of proteins involved in apoptosis induction and cell cycle arrest. In particular we observed the overexpression and relocalization of Bax leading to the activation of a mitochondria apoptotic pathway after irradiation. Moreover, we investigated the molecular mechanisms underlying the ICG-mediated photodynamic therapy (PDT) cell death focusing on the preferential expression of clusterin proapoptotic isoform and $\mathrm{Ku}$ proteins that regulate Baxdriven apoptotic death. 
Table 1. Protein expression evaluation by immunocytochemistry

\begin{tabular}{lllllll}
\hline ICC & UN & Laser 24h & ICG & $\begin{array}{l}\text { ICG } \\
+ \text { laser } 1 \mathrm{~h}\end{array}$ & $\begin{array}{l}\text { ICG } \\
+ \text { laser } 4 \mathrm{~h}\end{array}$ & $\begin{array}{l}\text { ICG } \\
+ \text { laser 24 h }\end{array}$ \\
\hline Bax & $\mathrm{c}+/-$ & $\mathrm{c}+/-$ & $\mathrm{c}+$ & $\mathrm{c}++/-$ & $\mathrm{c}++$ & $\mathrm{c}+++$ \\
Ku70 & $\mathrm{n}+++$ & $\mathrm{n}+++$ & $\mathrm{n}+++$ & $\mathrm{n}+++$ & $\mathrm{n}+++$ & $\mathrm{n}++++$ \\
Ku80 & $\mathrm{n}++$ & $\mathrm{n}++$ & $\begin{array}{l}\mathrm{n}++ \\
\mathrm{c}+/-\end{array}$ & $\mathrm{n}++$ & $\mathrm{n}+++$ & $\mathrm{n}++++$ \\
Clusterin & $\mathrm{n}+$ & $\mathrm{n}+$ & $\mathrm{n}+$ & $\mathrm{n}+$ & $\mathrm{n}+++$ & $\begin{array}{l}\mathrm{n}++ \\
\mathrm{c}+\text { + }+\end{array}$ \\
& $\mathrm{c}+$ & $\mathrm{c}+$ & $\mathrm{c}+/-$ & $\mathrm{c}+/-$ & $\mathrm{c}+/-$ \\
\hline
\end{tabular}

Immunostaining was scored as described in 'Materials and Methods' and cytoplasmic (c) or nuclear ( $\mathrm{n}$ ) localization of the proteins is indicated. Cells treated with $\mathrm{mP}$ laser alone (laser $24 \mathrm{~h}$ ) display a similar pattern as compared to untreated cells (UN). ICC = Immunocytochemistry.

\section{Materials and Methods}

\section{Cell Culture}

RPE cells ARPE-19 (American Type Culture Collection) were seeded in triplicate at subconfluent density $\left(4 \times 10^{4}\right.$ cells $\left./ \mathrm{cm}^{2}\right)$ in recommended medium. A day after seeding cells were incubated with monopeak iodine-free ICG (infracyanine, SERB Laboratories, Paris) to a final concentration of 500, 200 and $100 \mu \mathrm{M}$ and kept in the dark. Cell viability was evaluated after 1 and 2 days from ICG treatment in order to assess the nontoxic concentration and a 100- $\mu \mathrm{M}$ ICG concentration was chosen for all the laser irradiation experiments ( 5 independent experiments). One day after seeding cells were treated with ICG and kept in the dark for $24 \mathrm{~h}$. The following day, cells treated with ICG were exposed to 810 -nm laser irradiation. Cells not treated with ICG and incubated in the same conditions were exposed to the same laser irradiation. Unirradiated cells cultured in the presence or absence of ICG were used as controls. For quenching experiments, cells preloaded with ICG were treated with $\mathrm{NaN}_{3}$, a quencher of oxygen singlet, to a final concentration of $50 \mathrm{mM}, 1 \mathrm{~h}$ before laser exposure. Cells were counted at days 1, 2, 3 and 6 after laser treatment. Trypan blue staining was performed to evaluate cell death percentage.

\section{Laser Exposure}

ARPE-19 cells were seeded in triplicate in 96-well microtiter plates and incubated with $100 \mu \mathrm{M}$ IGC for $24 \mathrm{~h}$. Treated and untreated cells were incubated in the dark at $37 \mathrm{C}$ and $5 \% \mathrm{CO}_{2}$. Prior to laser exposure the supernatants were removed, cells were carefully washed with medium to eliminate any remaining dye and finally covered with drug-free medium. Irradiation was performed using an 810-nm diode laser (OcuLight SLx 810, Iridex Corporation, Mountain View, Calif., USA), delivered through a modified large spot slit lamp adapter set at $5 \mathrm{~mm}$ spot diameter. The distance between the laser source and the cell plates was adjusted to achieve a 6-mm diameter laser spot, adequate to cover a single well of a 96-well microtiter plate. Micropulse (mP) or CW laser emission was used for the ICG dye photoactivation. The $\mathrm{mP}$ laser setting was: power $=840 \mathrm{~mW}$, exposure time $=80 \mathrm{~s}$ (irradi-

ICG-Mediated Photo-Oxidative Cell Damage: DNA Repair and Cell Death ance $=2.97 \mathrm{~W} / \mathrm{cm}^{2}$ ), including a sequence of repetitive $300-\mu \mathrm{s}$ pulses interspaced by $1,700-\mu \mathrm{s}$ 'off' intervals ( $15 \%$ duty cycle). The CW laser setting was: power $=125 \mathrm{~mW}$, exposure time $=80 \mathrm{~s}$ (irradiance $=0.44 \mathrm{~W} / \mathrm{cm}^{2}$ ). These parameters produced an equal fluence (energy per unit of area) of $36 \mathrm{~J} / \mathrm{cm}^{2}$ for both $\mathrm{mP}$ and $\mathrm{CW}$ irradiation regimens. Cell viability was assessed by the trypan blue dye exclusion assay after 2, 3 and 6 days.

\section{Immunocytochemistry}

Cells were seeded on Nalge Nunc International Lab-Tek II Chamber Slide System at $4 \times 10^{4}$ cells $/ \mathrm{cm}^{2}$ and treated with ICG and laser radiation as described above. For immunostaining, cells were fixed in formaldehyde $4 \%$, permeabilized in $0.5 \%$ Triton X100 in PBS for $5 \mathrm{~min}$ and $0.05 \%$ Tween 20 in PBS for $5 \mathrm{~min}$ at room temperature and incubated with primary antibodies [goat polyclonal IgG anti-Ku70 (M-19) or anti-Ku80 (M-20), Santa Cruz Biotechnologies; rabbit polyclonal IgG anti-clusterin $\alpha / \beta(\mathrm{H}-$ 330), Santa Cruz Biotechnologies; mouse monoclonal IgG antiBax (Ab-1 2D2), Neo Markers; mouse monoclonal IgG anti-Bcl2 (clone BP53-12), YLEM] for $1 \mathrm{~h}$ at room temperature. Samples were washed extensively with $0.05 \%$ Triton X-100 in TBS and incubated with secondary biotinylated antibodies for $40 \mathrm{~min}$ at room temperature. After an extensive washing with $0.05 \%$ Triton $\mathrm{X}-100$ in TBS, samples were incubated for $30 \mathrm{~min}$ with HRPstreptavidin complex. All slides were counterstained with hematoxylin and were blindly evaluated for immunostaining and protein localization by 2 independent observers. The staining was semiquantitatively graded for intensity as negative $(+/-)$, weak (+ or $++/-)$, moderate $(++)$, strong $(+++)$ and very strong $(++++)$. The results are shown in table 1 .

\section{Protein Extraction and Western Blotting}

Cells were seeded and treated with ICG and laser as described above. They were processed for protein extraction after 1, 4 and $24 \mathrm{~h}$ from laser irradiation, and washed once with PBS and centrifuged $1 \mathrm{~min}$ at 10,000 rpm. The pellet was suspended in $40 \mu \mathrm{l}$ of sample buffer ( $0.06 \mathrm{M}$ Tris- $\mathrm{HCl}, \mathrm{pH} 6.8,25 \%$ glycerol, $2 \%$ SDS, $0.01 \%$ bromophenol blue, $0.5 \% \beta$-mercaptoethanol). Cellular debris was removed by centrifugation for $3 \mathrm{~min}$ in a microfuge at 

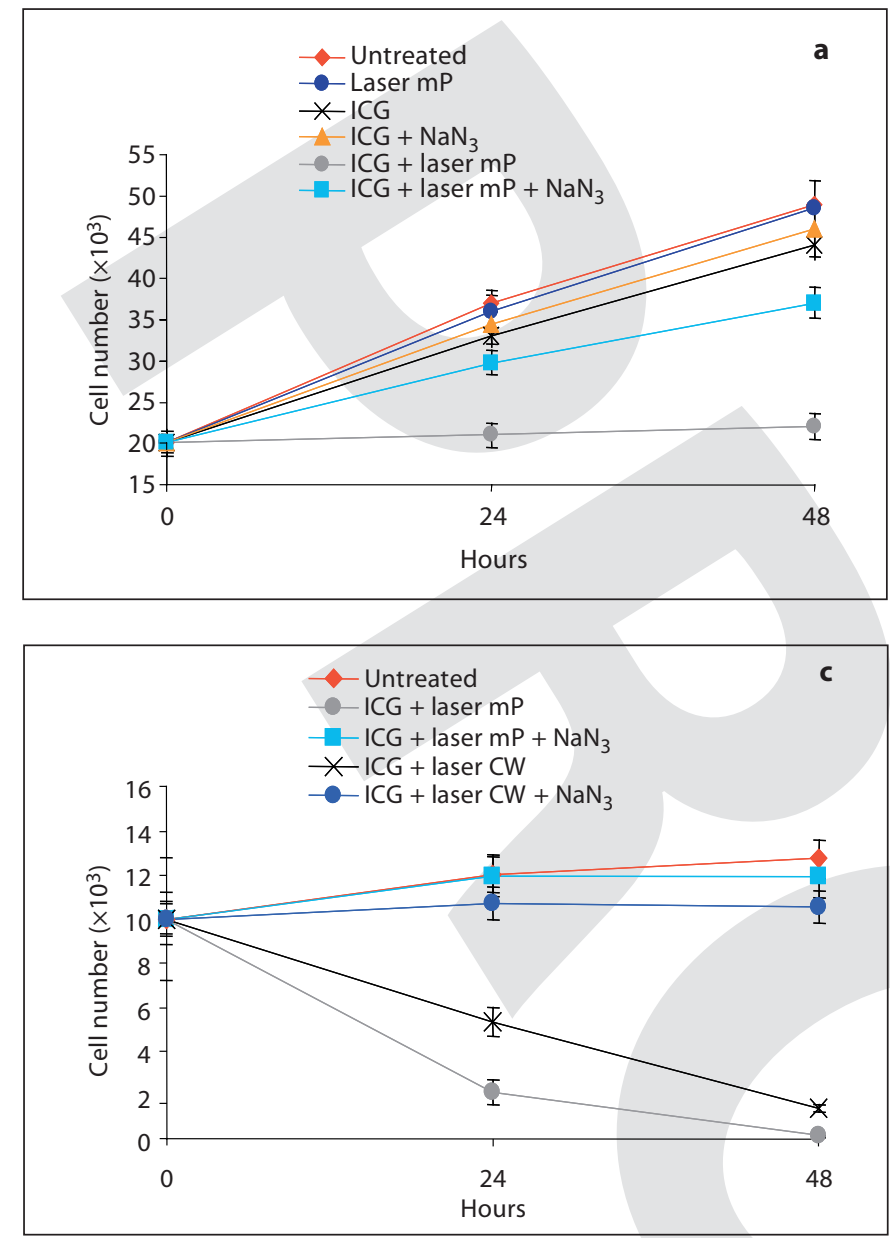

Fig. 1. Growth inhibitory and proapoptotic effect of ICG-mediated laser irradiation on ARPE-19. a Evaluation of cell proliferation by the trypan blue dye exclusion test after micropulsed laser irradiation in cells incubated for $24 \mathrm{~h}$ with (ICG + laser $\mathrm{mP}$ ) or without ICG (laser $\mathrm{mP}$ ) in the absence or in the presence of the quencher sodium azide (ICG + laser $\mathrm{mP}+\mathrm{NaN}_{3}$ ), as described in 'Materials and Methods'. The effect of ICG alone (ICG) or ICGpreloaded cells with the addition of $\mathrm{NaN}_{3}$ on cell proliferation in unirradiated cells is also represented. ARPE-19 cells incubated in cell medium alone and not irradiated were used as control. Values are means of 5 independent experiments \pm standard deviations (error bars). b Apoptosis induction in $100 \mu \mathrm{M}$ ICG-preloaded

$12,000 \mathrm{rpm}$ and the supernatant fraction containing the proteins was stored at $-20 \mathrm{C}$. Proteins were separated by $10 \%$ SDS-PAGE and transferred to a PVDF membrane (Hybond-P Amersham Lifescience). The PVDF membrane was incubated for $1 \mathrm{~h}$ at room temperature with 2.5\% NFDM, 2.5\% BSA TBS. Primary antibodies [mouse monoclonal IgG anti-Bax (YTH-2D2), TACS, goat polyclonal IgG anti-Ku70 (C-19), mouse monoclonal IgG anti$\mathrm{Ku} 80$ (B-1), rabbit polyclonal IgG anti-clusterin $\alpha / \beta$ (H-330), Santa Cruz Biotechnologies; rabbit polyclonal anti-caspase-3 (CPP32), Pharmingen, BD Biosciences] were incubated for $1 \mathrm{~h}$ at
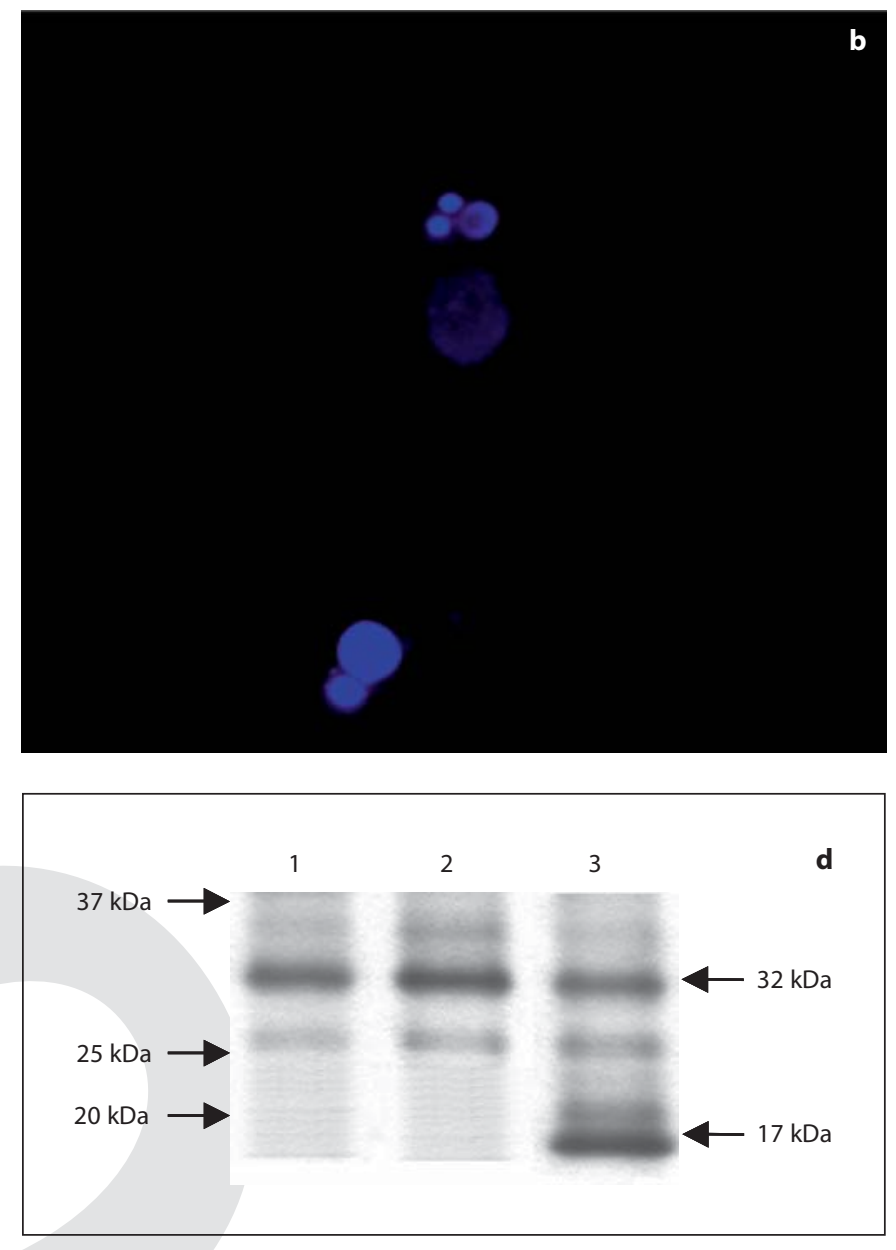

ARPE-19 cells after $24 \mathrm{~h}$ from micropulsed irradiation assessed by the Hoechst assay. c Effect of different laser irradiations in the presence or absence of ICG. Inhibition of cell growth was evaluated by the trypan blue dye exclusion test, after 24 and $48 \mathrm{~h}$ from irradiation. Values are means of 5 independent experiments \pm standard deviations (error bars). d Western blot analysis of caspase-3 expression in ARPE-19 whole-cell extracts: untreated cells (lane 1), ICG-stained cells (lane 2), ICG-stained cells $24 \mathrm{~h}$ after $\mathrm{mP}$ laser irradiation (lane 3 ). The $32-\mathrm{kDa}$ procaspase- 3 is expressed as in all cells but in ICG-irradiated cells it is decreased $24 \mathrm{~h}$ after irradiation, forming the $17-\mathrm{kDa}$ active caspase- 3 .

room temperature. The PVDF membrane was washed extensively with $0.5 \%$ Tween 20 TBS and incubated with secondary antibodies (anti-mouse-HRP IgG, Amersham Lifescience; anti-goatHRP IgG, anti-rabbit IgG, Santa Cruz Biotechnologies) for $45 \mathrm{~min}$ at room temperature. The filter was reprobed with anti- $\beta$-actin (clone AC-15, Sigma-Aldrich) mouse monoclonal IgG antibody to normalize protein levels. The filter was washed and developed using an enhanced chemiluminescence system (Amersham Pharmacia Biotech). 
Table 2. Effect of ICG treatment on ARPE-19 viability

\begin{tabular}{rrlll}
\hline & Medium & $100 \mu \mathrm{M}$ ICG & $200 \mu \mathrm{M}$ ICG & $500 \mu \mathrm{M}$ ICG \\
\hline $24 \mathrm{~h}$ & $9 \pm 0.78$ & $10 \pm 0.18$ & $39 \pm 0.25^{1}$ & $55 \pm 0.88^{1}$ \\
$48 \mathrm{~h}$ & $12 \pm 0.95$ & $11 \pm 0.78$ & $50 \pm 0.77^{1}$ & $87 \pm 0.22^{1}$ \\
\hline
\end{tabular}

Cell death percentage was evaluated by the trypan blue dye exclusion test, obtained as (dead cell number/total cell number) $\times 100$ and mean \pm standard deviation from 3 independent experiments. Values were compared using the 2-tailed t-test.

${ }^{1}$ Medium versus $200 \mu \mathrm{M}$ ICG and medium versus $500 \mu \mathrm{M}$ ICG: $\mathrm{p}<0.05$.

\section{Results}

ICG-Mediated PDT-Induced Apoptosis in ARPE Cells

The effect of ICG staining and laser irradiation on cell proliferation was observed in a retinal epithelial cell line (ARPE-19) in 5 independent experiments (fig. 1). Each individual experiment was carried out using triplicate samples. Primarily, to examine whether ICG loading induced cell death, ARPE-19 cells were incubated for $24 \mathrm{~h}$ at $37^{\circ} \mathrm{C}$ under dark conditions with different concentrations of ICG dye (500, 200 and $100 \mu \mathrm{M})$ and cell viability was assessed as shown in table 2. ICG-untreated cells maintained in the same conditions were used as control. The effect of ICG on cell death induction was assessed after $24 \mathrm{~h}$ and evaluated by the trypan blue dye exclusion test and the Hoechst assay. ARPE-19 cells maintained their monolayer morphology after incubation only with $100 \mu \mathrm{M}$ ICG. The observation of ARPE-19 cells stained with hematoxylin and eosin after an overnight incubation with $100 \mu \mathrm{M}$ ICG alone demonstrated an increased mitotic index (not shown). Conversely, the 24-hour incubation with an increasing concentration of ICG induced a statistically significant amount of apoptosis in ARPE-19 cells at 200 and $500 \mu \mathrm{M}$ as assessed by the Hoechst assay (not shown).

Successively, we evaluated the effects of $810-\mathrm{nm}$ micropulsed laser irradiation at $36 \mathrm{~J} / \mathrm{cm}^{2}$ fluence on the ARPE-19 cells proliferation (fig. 1). A day after seeding, cells were incubated with or without $100 \mu \mathrm{M}$ ICG dye. Laser emission was modulated in a micropulsed regimen as described in 'Materials and Methods'. As expected, laser irradiation alone in ARPE-19 cells not preloaded with ICG had no effect on cell proliferation and viability. As shown in figure $1 \mathrm{a}$ and $\mathrm{c}$, laser treatment resulted in growth inhibition of ICG-treated cells compared to unirradiated cells ICG pretreated on day 2 after laser irradia-

ICG-Mediated Photo-Oxidative Cell Damage: DNA Repair and Cell Death tion. Moreover, ICG photoactivation at $810 \mathrm{~nm}$ effectively induced apoptosis after $24-48 \mathrm{~h}$ in the ARPE-19 cell line. This was assessed both by Hoechst assay (fig. 1b) as well as by the use of an antibody that is able to recognize the $32-\mathrm{kDa}$ unprocessed procaspase- 3 and the $17-\mathrm{kDa}$ active caspase-3. Western blot analysis of whole cell lysates demonstrated the presence of the uncleaved caspase- 3 in untreated and ICG-treated ARPE-19 cells, while ICGpreloaded irradiated cells expressed both the unprocessed and the active forms of caspase-3 (fig. 1d). Cell death was considerably reduced by the addition of the singlet oxygen quencher sodium azide $\left(\mathrm{NaN}_{3} 50 \mathrm{mM}\right)$ to the medium, suggesting the involvement of reactive oxygen species in the machinery of photo-oxidative cell damage (fig. 1a, c). The proliferation rate of ARPE-19 cells is linked to their starting number and the effect of ICG and laser treatment (and of the cotreatment) is more dramatic when cells are not at confluence. Moreover, the cellular damage induced by the photoactivation of ICG-loaded ARPE-19 cells with the same fluence $\left(36 \mathrm{~J} / \mathrm{cm}^{2}\right)$ delivered with 2 irradiation modalities, continuous $\mathrm{CW}$ and $\mathrm{mP}$ waves were also compared (fig. 1c). In the CW modality, a constant laser irradiance $\left(0.45 \mathrm{~W} / \mathrm{cm}^{2}\right)$ was delivered for the entire 80-second exposure time, while in the $\mathrm{mP}$ modality a higher irradiance $\left(3.0 \mathrm{~W} / \mathrm{cm}^{2}\right)$ was delivered for $80 \mathrm{~s}$ in a sequence of very short laser pulses at a $15 \%$ duty cycle (of $300 \mu \mathrm{s}$ 'on', separated by $1,700 \mu \mathrm{s}$ 'off' time), with exactly the same total energy per unit of area of 36 $\mathrm{J} / \mathrm{cm}^{2}$ delivered in both modalities. The $\mathrm{mP}$ laser irradiation induced a higher percentage of cell killing after only $24 \mathrm{~h}$ as compared to CW (fig. 1c). Moreover, cell death was significantly reduced when $50 \mathrm{mM}$ of sodium azide was added to cell culture $1 \mathrm{~h}$ before laser exposure independently of laser emission regimen (fig. 1c), confirming a strong protective effect from ICG-mediated photo-oxidative damage.

\section{Induction of the Proapoptotic Machinery}

Immunocytochemistry was performed to evaluate the expression and localization of gene products involved in DNA repair and apoptosis. Cells were seeded as described in 'Materials and Methods' and incubated $24 \mathrm{~h}$ in the presence or absence of ICG. Cells were irradiated with $\mathrm{mP}$ wave as already described. Unirradiated cells were used as control. Clusterin expression was evaluated with an antibody anti- $\beta$-chain recognizing all clusterin isoforms. As shown in figure 2, clusterin was expressed at basal level as in the cytoplasm and in the nucleus in untreated cells. The ICG pretreatment induced a slight increase of clusterin nuclear isoform probably linked to its 


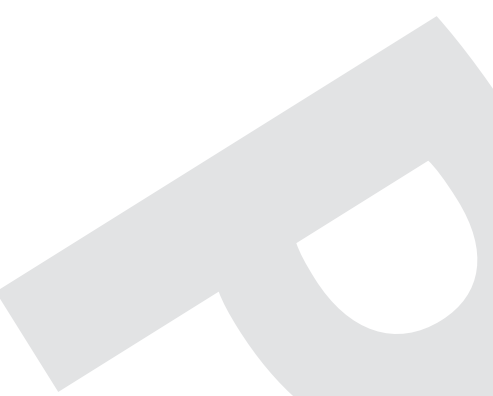

Fig. 2. Clusterin expression and localization was modulated by ICG photoactivation at $810 \mathrm{~nm}$. Immunocytochemistry in ARPE-19 untreated (UN), ICG-treated (+ICG) or ICG- and mP-laser-cotreated cells $(+\mathrm{ICG}+\mathrm{L} 4 \mathrm{~h}$; +ICG $+\mathrm{L} 24 \mathrm{~h}$ ) for clusterin expression. After 4 and $24 \mathrm{~h}$ from the cotreatment only the proapoptotic nuclear form was present in the nucleus mediating the proapoptotic effect of ICG-mediated PDT.

Fig. 3. ICG photoactivation at $810 \mathrm{~nm}$ induced an overexpression of Bax. Immunocytochemistry of ARPE-19 unirradiated cells incubated in the absence (UN) or in the presence of ICG (+ICG) and ICG-preloaded and mP-laser-treated cells $(+\mathrm{ICG}$ +L $4 \mathrm{~h}$; +ICG +L 24 h) stained with antiBax monoclonal antibody. A strong induction and relocalization of Bax can be observed after 4 and $24 \mathrm{~h}$ from cotreatment.
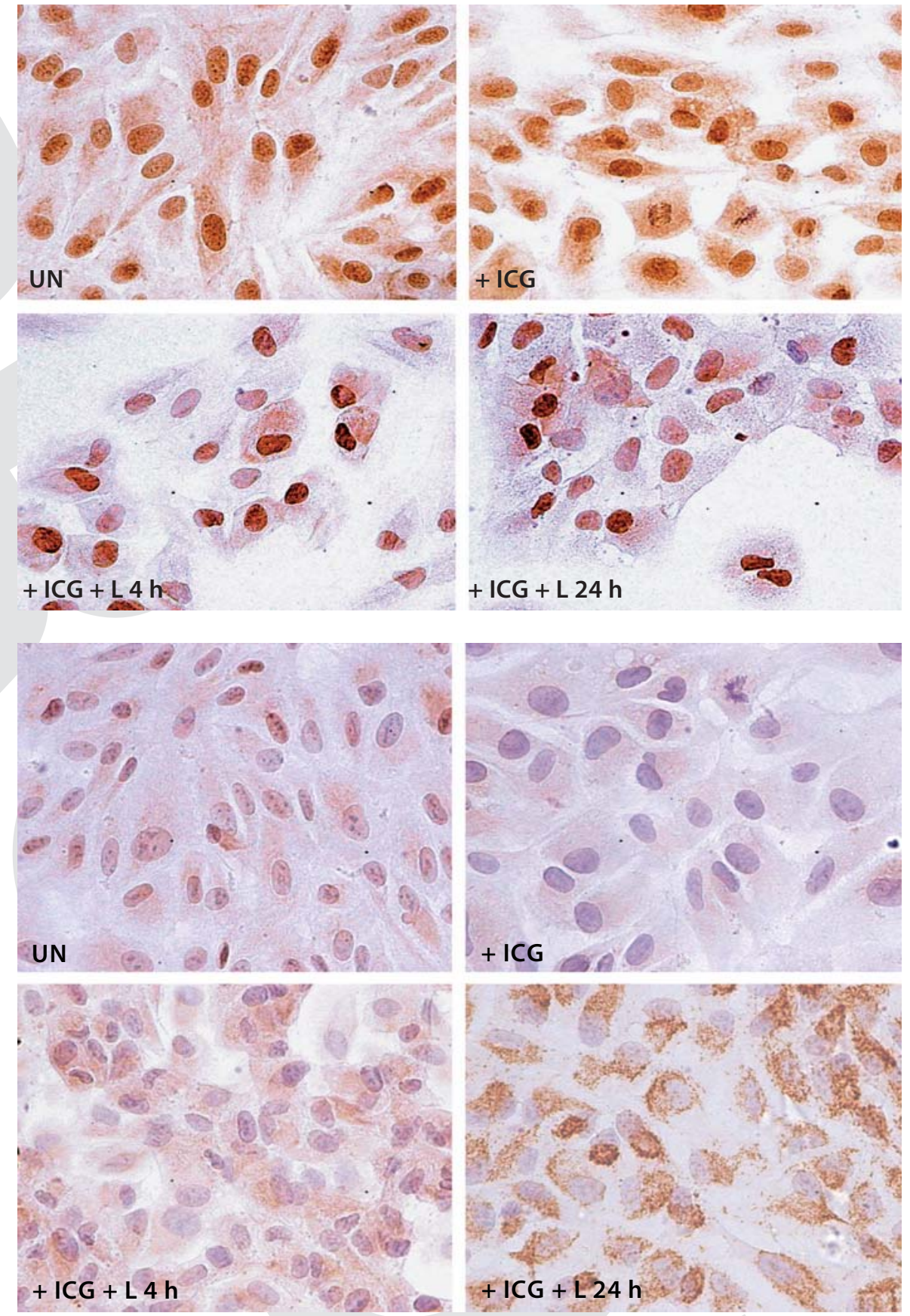

effects on cell cycle regulation. After 1, 4 and $24 \mathrm{~h}$ a strong increase of the nuclear proapoptotic isoform accompanied by the loss of the cytoplasmic form was induced by $\mathrm{mP}$ laser irradiation (fig. 2). Conversely, cells irradiated with CW laser share a different pattern of clusterin isoform expression. In fact, in ICG-preloaded cells irradiated with the CW, no induction of the nuclear proapoptotic form was obtained after 1-24 h of treatment (data not shown). The expression of the proapoptotic member of the Bcl-2 family, Bax, was also determined by immunocytochemistry. Bax staining was faint in the cytoplasm of ICG-preloaded unirradiated cells and untreated cells used as controls. Conversely, irradiation of ICG-stained cells considerably increased the expression of Bax in particular $24 \mathrm{~h}$ after the laser treatment (fig. 3). Ku70 and $\mathrm{Ku} 80$ are proteins involved in DNA repair and apoptosis 


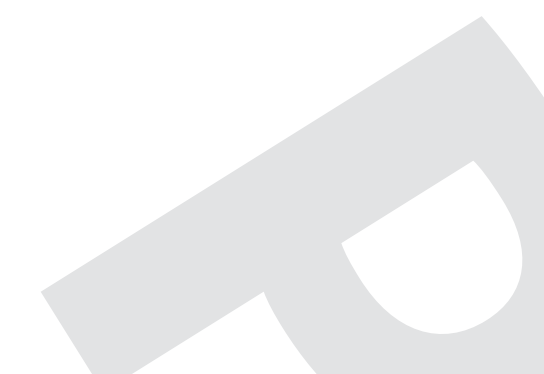

Fig. 4. Modulation of Ku80 expression. Ku80 expression evaluated by immunocytochemistry in untreated (UN), ICG-treated (+ICG) or PDT-treated cells at different times. An increased cytoplasmatic expression $24 \mathrm{~h}$ after $\mathrm{mP}$ laser irradiation (+ICG $+\mathrm{L} 24 \mathrm{~h}$ ) appeared, suggesting that a photo-oxidative (type 2) mechanism induced DNA cell damage. Laser irradiation of ICG-preloaded cells (+ICG +L 4 h; +ICG $+\mathrm{L} 24 \mathrm{~h}$ ) did not inhibit the induction of the protein involved in DNA double strand break repair usually inhibited by hyperthermic effects.

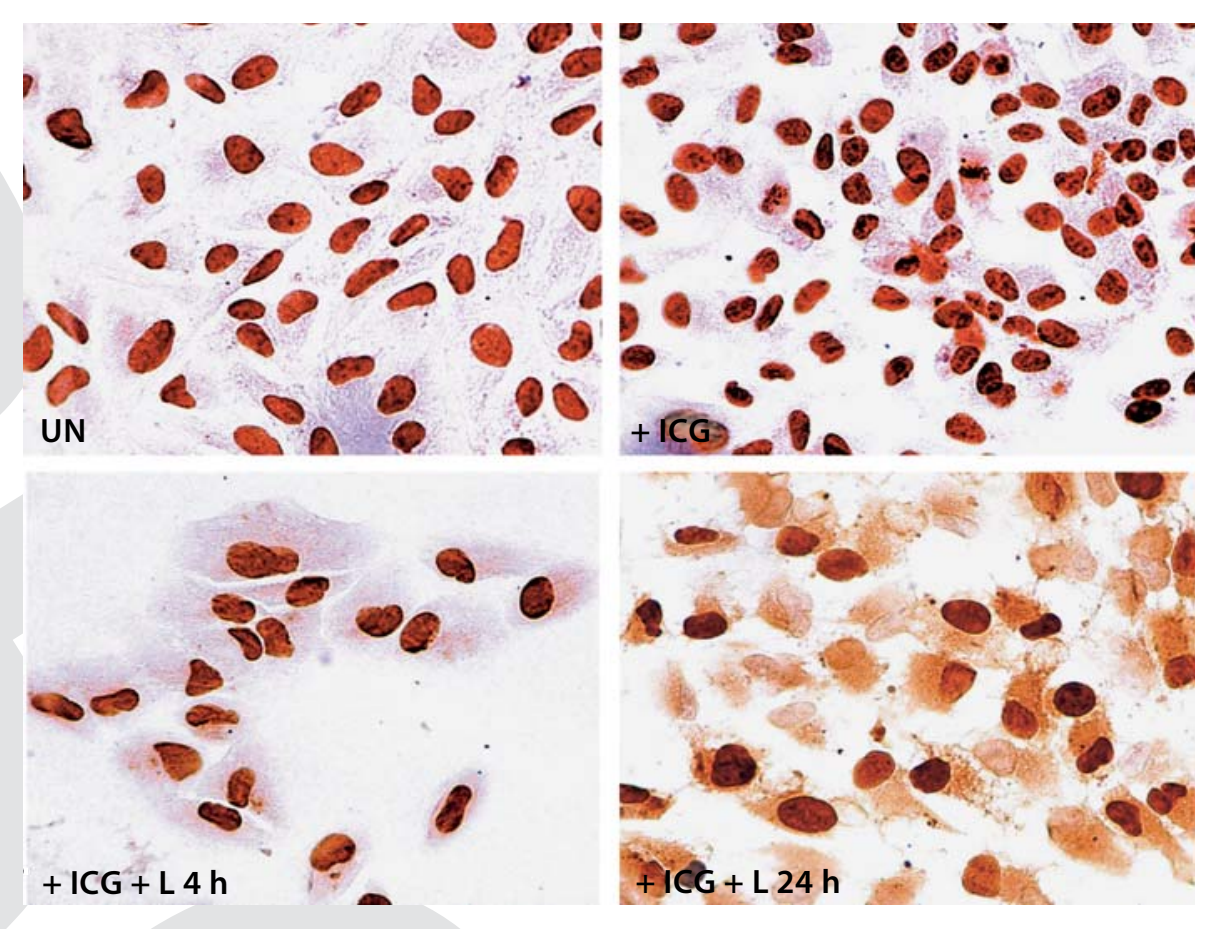

induction. The expression and modulation of these 2 components of the multicomplex DNA-PK are strongly inhibited if the damage is due to hyperthermia. After the ICG photoactivation at $810 \mathrm{~nm}$ by means of $\mathrm{mP}$ irradiation, Ku80 showed an increased expression (fig. 4), supporting the hypothesis that the DNA cell damage is related to a photo-oxidative mechanism rather than heating. After $24 \mathrm{~h}, \mathrm{Ku} 80$ relocalized from the nucleus into the cytoplasm, as shown in figure 4 .

\section{Proapoptotic Clusterin Isoform, Bax and Ku}

Induction in Micropulsed Laser-Irradiated Cells

Western blot analysis was performed to evaluate the DNA damage or apoptosis induction in ARPE-19 ICGloaded cells with or without $\mathrm{mP}$ laser irradiation. Whole cell lysates were prepared from ICG-stained irradiated cells and ICG-stained nonirradiated cells were used as control. In order to clarify whether cell damage is due to a photo-oxidative rather than a photothermal effect, Ku70 and Ku80 expression was analyzed by Western blot. The results obtained showed that the expression of both $\mathrm{Ku} 70$ and Ku 80 increased 4 and $24 \mathrm{~h}$ after $\mathrm{mP}$ laser irradiation of ICG-preloaded cells as compared to the control (fig. 5a). Moreover, Ku70 and Ku 80 expression was also demonstrated in the cytoplasm after $24 \mathrm{~h}$, as shown in figure 4 for $\mathrm{Ku} 80$. These results are in agreement with the DNA repair role of the heterodimer complex in response

ICG-Mediated Photo-Oxidative Cell Damage: DNA Repair and Cell Death to direct photo-oxidative effect on DNA. The expression of Bax was also shown to increase by Western blot in cells treated with ICG and laser (fig. 5b), in agreement with the strong apoptosis induction observed. The expression of different isoforms of clusterin was also assessed because of its role in cell cycle progression and cell death induction. Western blot analysis demonstrated that apoptosis induced by ICG photoactivation was associated with a complete disappearance of the clusterin secreted form. In untreated cells, the clusterin proapoptotic nuclear form $(50 \mathrm{kDa})$ was less expressed as compared to the secreted form $(40 \mathrm{kDa})$, but the nuclear proapoptotic form was strongly induced after $24 \mathrm{~h}$ of treatment, as shown by immunocytochemistry (fig. 2) and confirmed by Western blot (fig. 5b).

\section{Discussion}

In the present work we demonstrated that ICG-preloaded ARPE-19 cells can be effectively damaged in vitro by ICG photoactivation at $810 \mathrm{~nm}$. Laser irradiation with a low energy density $\left(36 \mathrm{~J} / \mathrm{cm}^{2}\right)$ significantly decreased cell viability, inducing apoptosis. The ICG-mediated photo-oxidative damage occurs with both $\mathrm{CW}$ and $\mathrm{mP}$ irradiation modalities. The latter has a more pronounced effect and this could be due to higher laser irradiance of 
its micropulses with synergistic photothermal (heat conversion by the ICG dye) and photochemical (ICG photooxidation) cytotoxic damage mechanisms. The absence of photothermal damage is demonstrated by the fact that the addition of sodium azide prior to laser photoactivation effectively prevents cellular damage, although the protection by this quencher can only be effective against photo-oxidative damage. Similar experiments in vitro, using different cell lines and an adequate setup, yielded a similar mechanism of photochemical damage (unpublished data). The higher photodynamic efficiency of the $\mathrm{mP}$ laser regimen could be related to the fact that fragmented irradiation does not deplete cell culture oxygen supply as rapidly as CW irradiation [28]. ICG-mediated photo-oxidative killing of ARPE-19 cells induces DNA damage in a high percentage of cells. Moreover, the observation of ARPE-19 cell cultures stained with hematoxylin and eosin showed that the addition of ICG induces chromatin condensation, leading to an increased mitotic index compared to ICG-untreated cells. These data could suggest a potential key role of ICG not only as photosensitizing agent but also in synchronizing the cells in a particular cell cycle phase, increasing the percentage of elements sensitive to photo-oxidative damage induction. Therefore, the photoactivation effect of ICG on apoptosis induction could be directly related to the effect of ICG on the cell cycle [29]. Our results demonstrated that only after $4-24 \mathrm{~h}$ from the treatment, Ku70 and Ku80 are activated to repair DNA damage. The increased expression of Ku80 $24 \mathrm{~h}$ after photo-oxidative damage was associated with increased Ku80 expression in the cytoplasm, as demonstrated by immunocytochemistry. The data obtained on Ku70/80 activation suggest that the damage was due to a photo-oxidative effect because in the presence of an oxygen singlet quencher such as $\mathrm{NaN}_{3}$ the damage was inhibited. Indeed, ARPE-19 cells do not display an impaired viability only when $\mathrm{NaN}_{3}$ is present in the medium during laser exposure. The results on an increased expression of Ku70 and Ku80 subunits demonstrated that DNA damage is due to oxidative stress mediated by ICG photo-oxidation at $810 \mathrm{~nm}$.

Moreover, the oxidative stress determined by reactive oxygen species formation seems to induce a different kinetic effect on $\mathrm{Ku} 70 / 80$ presence, as has been published by Song et al. [25]. The activation of Bax and its relocalization in the mitochondria $24 \mathrm{~h}$ after laser irradiation are in agreement with the data published $[26,30]$ on the interaction between Ku70 and Bax during DNA damage. In fact, Bax usually is inactive in the cytosol and Ku70 inhibits its translocation to the mitochondria and there-

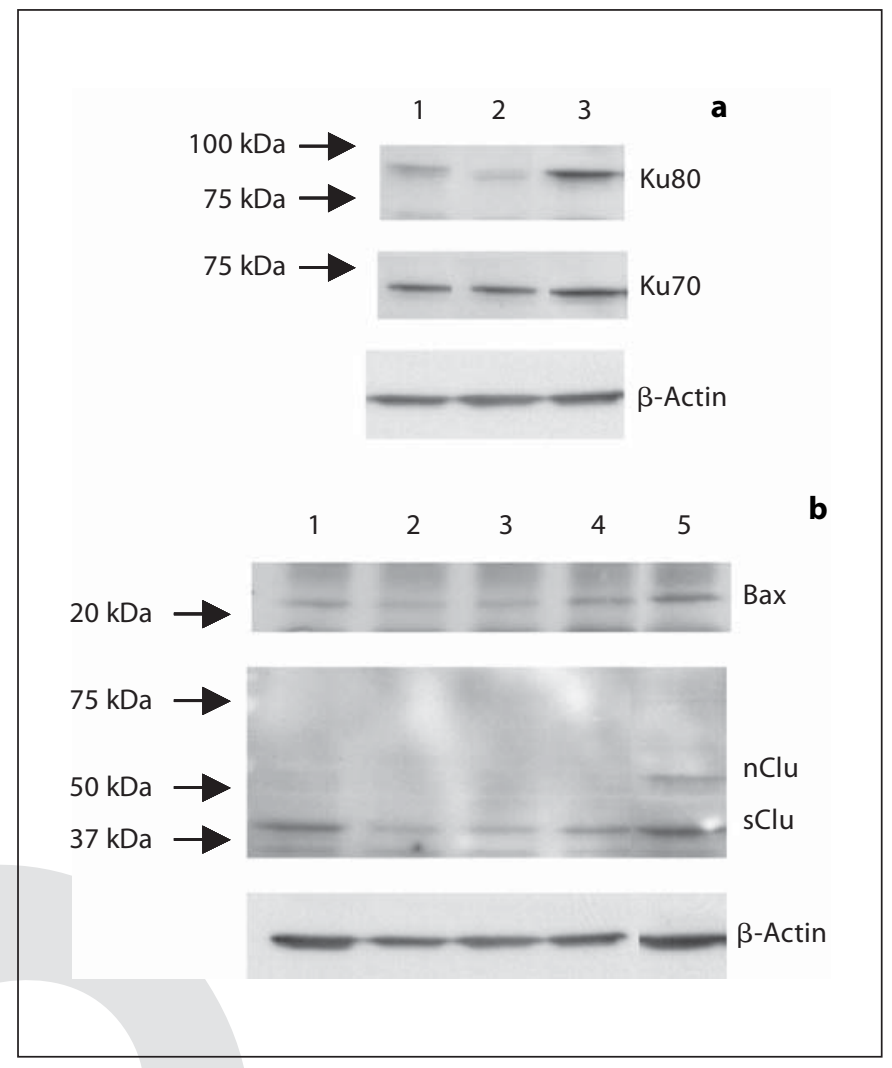

Fig. 5. Western blot analysis of ICG-stained ARPE-19 cells exposed to $\mathrm{mP}$ laser irradiation (fluence: $36 \mathrm{~J} / \mathrm{sec}$ ). a A representative Western blot analysis of Ku70 and Ku 80 expression in ARPE19 whole-cell extract: untreated cells (lane 1), ICG-stained cells $4 \mathrm{~h}$ after $\mathrm{mP}$ irradiation (lane 2), ICG-stained cells $24 \mathrm{~h}$ after $\mathrm{mP}$ irradiation (lane 3); $\beta$-actin housekeeping gene was used for normalization. The blot is representative of 3 independent experiments that gave similar results. b Western blot analysis of clusterin and Bax expression in ARPE-19 whole-cell extracts: untreated cells (lane 1), ICG-stained cells (lane 2), ICG-stained cells $1 \mathrm{~h}$ after $\mathrm{mP}$ laser irradiation (lane 3), ICG-stained cells $4 \mathrm{~h}$ after $\mathrm{mP}$ laser irradiation (lane 4), ICG-stained cells $24 \mathrm{~h}$ after $\mathrm{mP}$ laser irradiation (lane 5). The presence of the nuclear clusterin form is evident after $24 \mathrm{~h}$ in ICG-irradiated ARPE-19 cells. $\beta$-Actin was used for normalization. The blot is representative of 3 independent experiments that gave similar results. $\mathrm{nClu}=\mathbf{\square} \mathbf{\square} ; \mathrm{sClu}=$ ㅁ․

fore the induction of cell death. After DNA damage induction, Ku70 is activated, releases Bax and translocates to the nucleus, where it actively participates in DNA repair. Therefore, Bax activity is regulated by Ku70 release that promotes its translocation to the mitochondria, where it can act as a cell death promoting factor. A strong increase of clusterin proapoptotic nuclear isoform was evident only in ICG-preloaded cells irradiated with $\mathrm{mP}$ 
laser. The pattern shift of the different isoforms appears strictly linked to different biological functions. The preferential expression of the proapoptotic nuclear isoform induced by laser irradiation after $24 \mathrm{~h}$ regulates the laser damage induction of apoptotic death. Moreover, apoptotic death after irradiation is correlated to Ku70 activation that induces the relocalization of Bax into the mitochondria.

The association of the clusterin nuclear isoform with apoptosis induction has recently been clarified [27, 31]. Therefore, the strong induction of a proapoptotic isoform could in part explain why ICG photo-oxidation with a $\mathrm{mP}$ laser activation can induce apoptotic cell death more efficiently as compared to $\mathrm{CW}$ laser activation. These data in part elucidate the important role of ICG in synchronizing the targeted cell population and describe the molecular mechanism that could be involved in laser ICG-induced cell death.

ICG exhibits some characteristics of an ideal ophthalmic fluorophore photosensitizer, such as low toxicity, an absorption peak of $810 \mathrm{~nm}$ in human plasma, deeper tissue penetration and no significant retina phototoxicity of the activating radiation [32], as well as formation of the triplet state after irradiation with a quantum yield of $11 \%$ [33].

The potential of ICG as a photosensitizer was investigated in different studies. In an uncontrolled clinical trial, occult choroidal neovascularization in age-related macular degeneration was selectively closed using 1.5 $\mathrm{mg} / \mathrm{kg}$ of ICG at $3 \mathrm{~W} / \mathrm{cm}^{2}$ for $95 \mathrm{~s}$ (calculated as $285 \mathrm{~J} /$ $\mathrm{cm}^{2}$ ) [34]. In in vivo experiments the choriocapillaris of normal rabbits was closed successfully using PDT mediated by higher ICG doses $(10-20 \mathrm{mg} / \mathrm{kg})$ and an $810-\mathrm{nm}$ diode laser at a fluence of $6.3 \mathrm{~J} / \mathrm{cm}^{2}$ [35]. Since choriocapillaris occlusion was always associated with some degree of RPE damage in this and in other studies [36,37], the authors hypothesized that the RPE damage could be related to choroidal ischemia. Other authors reported RPE damage even in the absence of choriocapillaris photodynamic injury, suggesting that RPE involvement may be related to a direct photo-oxidative effect [38].

Furthermore, histological studies demonstrated that after IV injection the ICG extravasates from choroidal vessel and selectively accumulates within the RPE cells in the human eye $[39,40]$.

Therefore, it is not unreasonable to postulate that the exposure of ICG-stained RPE to low fluence laser radiation could lead to a selective photo-oxidative cell killing in vivo.

Further investigations concerning the photosensitizer dose, the timing of the start of irradiation, laser power and duration are required to evaluate if PDT, performed with the $810-\mathrm{nm} \mathrm{mP}$ laser, and ICG could be used in a clinical setting to achieve a selective RPE damage.

\section{References}

1 Early Treatment Diabetic Retinopathy Study Research Group: Photocoagulation for diabetic macular edema: Early Treatment Diabetic Retinopathy Study report number 1 . Arch Ophthalmol 1985;103:1796-1806.

2 Akduman L, Olk RJ: Diode laser (810 nm) versus argon green $(514 \mathrm{~nm})$ modified grid photocoagulation for diffuse diabetic macular edema. Ophthalmology 1997;104:14331441.

3 Lee CM, Olk RJ: Modified grid laser photocoagulation for diffuse diabetic macular edema: long-term visual results. Ophthalmology 1991;98:1594-1602.

4 Del Priore LV, Glaser BM, Quigley HA, Green WR: Response of pig retinal pigment epithelium to laser photocoagulation in organ culture. Arch Ophthalmol 1989;107: 119-122.

5 Smiddy WE, Fine SL, Quigley HA, Dunkelberger G, Hohmann RM, Addicks EM: Cell proliferation after laser photocoagulation in primate retina: an autoradiographic study. Arch Ophthalmol 1986;104:1065-1069.
6 Wallow IH: Repair of the pigment epithelial barrier following photocoagulation. Arch Ophthalmol 1984;102:126-135.

7 Brancato R, Pratesi R, Leoni G, Trabucchi G, Vanni U: Histopathology of diode and argon laser lesions in rabbit retina: a comparative study. Invest Ophthalmol Vis Sci 1989;30: 1504-1510.

8 Smiddy WE, Fine SL, Green WR, Glaser BM: Clinicopathologic correlation of krypton red, argon blue-green, and argon green laser photocoagulation in the human fundus. Retina $1984 ; 4: 15-21$

9 Smiddy WE, Hernandez E: Histopathologic characteristics of diode laser-induced chorioretinal adhesions for experimental retinal detachment in rabbit eyes. Arch Ophthalmol 1992;110:1630-1633.

10 Framme C, Brinkmann R, Birngruber R, Roider J: Auto-fluorescence imaging after selective RPE laser treatment in macular diseases and clinical outcome: a pilot study. $\mathrm{Br}$ J Ophthalmol 2002;86:1099-1106.
11 Roider J, Michaud NA, Flotte TJ, Birngruber $\mathrm{R}$ : Response of the retinal pigment epithelium to selective photocoagulation. Arch Ophthalmol 1992;110:1786-1792.

12 Ogata N, Tombran-Tink J, Jo N, Mrazek D, Matsumura M: Upregulation of pigment epithelium-derived factor after laser photocoagulation. Am J Ophthalmol 2001;132:427429.

13 Wilson AS, Hobbs BG, Shen WY, Speed TP, Schmidt U, Begley CG, Rakoczy PE: Argon laser photocoagulation-induced modification of gene expression in the retina. Invest Ophthalmol Vis Sci 2003;44:1426-1434.

14 Dorin G: Evolution of retinal laser therapy: minimum intensity photocoagulation (MIP) - Can the laser heal the retina without harming it? Semin Ophthalmol 2004; 19:62-68.

15 Anderson R, Parrish JA: Selective photothermolysis: precise microsurgery by selective absorption of pulsed radiation. Science 1983; 220:524-527. 
16 Mainster MA: Decreasing retinal photocoagulation damage: principles and techniques. Semin Ophthalmol 1999;14:200209.

17 Pollack JS, Kim JE, Pulido JS, Burke JM: Tissue effects of subclinical diode laser treatment of the retina. Arch Ophthalmol 1998; 116:1633-1639.

18 Desmettre T, Maurage CA, Mordon S: Heat shock protein hyperexpression on chorioretinal layers after transpupillary thermotherapy. Invest Ophthalmol Vis Sci 2001;42:29762980.

19 Abels C, Fickweiler S, Weiderer P, Baumler W, Hofstadter F, Landthaler M, Szeimies RM: Indocyanine green (ICG) and laser irradiation induce photooxidation. Arch Dermatol Res 2000;292:404-411.

20 Baumler W, Abels C, Karrer S, Weiss T, Messmann H, Landthaler M, Szeimies RM Photo-oxidative killing of human colonic cancer cells using indocyanine green and infrared light. Br J Cancer 1999;80:360-363.

21 Fickweiler S, Szeimies RM, Baumler W, Steinbach P, Karrer S, Goetz AE, Abels C, Hofstadter F, Landthaler M: Indocyanine green: intracellular uptake and phototherapeutic effects in vitro. J Photochem Photobiol B 1997;38:178-183.

22 Urbanska K, Romanowska-Dixon B, Matuszak Z, Oszajca J, Nowak-Sliwinsk P, Stochel G: Indocyanine green as a prospective sensitizer for photodynamic therapy of melanomas. Acta Biochim Pol 2002;49:387391.

23 Burgman P, Ouyang H, Peterson S, Chen DJ, Li GC: Heat inactivation of $\mathrm{Ku}$ autoantigen: possible role in hyperthermic radiosensitization. Cancer Res 1997;57:2847-2850.

24 Ihara M, Suwa A, Komatsu K, Shimasaki T, Okaichi K, Hendrickson EA, Okumura Y: Heat sensitivity of double-stranded DNAdependent protein kinase (DNA-PK) activity. Int J Radiat Biol 1999;75:253-258.
25 Song JY, Lim JW, Kim H, Morio T, Kim KH: Oxidative stress induces nuclear loss of DNA repair proteins Ku70 and Ku80 and apoptosis in pancreatic acinar AR42J cells. J Biol Chem 2003;278:36676-36687.

26 Sawada M, Sun W, Hayes P, Leskov K, Boothman DA, Matsuyama S: Ku70 suppresses the apoptotic translocation of Bax to mitochondria. Nat Cell Biol 2004;5:320-329.

27 Pucci S, Bonanno E, Pichiorri F, Angeloni C, Spagnoli LG: Modulation of different clusterin isoforms in human colon tumorigenesis. Oncogene 2004;23:2298-2304.

28 Varriale L, Crescenzi E, Paba V, di Celso BM, Palumbo G: Selective light-induced modulation of bcl-XL and bax expressions in indocyanine green-loaded U937 cells: effects of continuous or intermittent photo-sensitization with low IR-light using a $805-\mathrm{nm}$ diode laser. J Photochem Photobiol B 2000;57:6675.

29 Yam HF, Kwok AK, Chan KP, Lai TY, Chu KY, Lam DS, Pang CP: Effect of indocyanine green and illumination on gene expression in human retinal pigment epithelial cells. Invest Ophthalmol Vis Sci 2003;44:370377.

30 Cohen HY, Lavu S, Bitterman KJ, Hekking B, Imahiyerobo TA, Miller $\mathrm{C}$, Frye R, Ploegh $\mathrm{H}$, Kessler BM, Sinclair DA: Acetylation of the $\mathrm{C}$ terminus of Ku70 by CBP and PCAF controls Bax-mediated apoptosis. Mol Cell 2004; 13:627-638

31 Orlandi A, Pucci S, Ciucci A, Pichiorri F, Ferlosio A, Spagnoli LG: Modulation of clusterin isoforms is associated with all-trans retinoic acid-induced proliferative arrest and apoptosis of intimal smooth muscle cells. Arterioscler Thromb Vasc Biol 2005;25:348353.

32 Mainster MA, Reichel E: Transpupillary thermotherapy for age-related macular degeneration: long-pulse photocoagulation, apoptosis, and heat shock proteins. Ophthalmic Surg Lasers 2000;31:359-373.
33 Reindl S, Penzkofer A, Gong SH, Landthaler M, Szeimies RM, Abels C, Bäumler W: Quantum yield of triplet formation for indocyanine green. J Photochem Photobiol Chem 1997; 105:65-68.

34 Costa RA, Farah ME, Cardillo JA, Belfort R Jr: Photodynamic therapy with indocyanine green for occult subfoveal choroidal neovascularization caused by age related macular degeneration. Curr Eye Res 2001;23:271275.

35 Costa RA, Farah ME, Freymuller E, Morales $\mathrm{PH}$, Smith R, Cardillo JA: Choriocapillaris photodynamic therapy using indocyanine green. Am J Ophthalmol 2001;132:557-565.

36 Wilson CA, Royster AJ, Tiedeman JS, Hatchell DL: Exudative retinal detachment after photodynamic injury. Arch Ophthalmol 1991;109:125-134.

37 Peyman GA, Moshfeghi DM, Moshfeghi A, Khoobehi B, Doiron DR, Primbs GB Crean DH: Photodynamic therapy for choriocapillaris using tin ethyl etiopurpurin (SnET2). Ophthalmic Surg Lasers 1997;28:409-417.

38 Yao XY, Marmor MF: Induction of serous retinal detachment in rabbit eyes by pigment epithelial and choriocapillary injury. Arch Ophthalmol 1992;110:541-546.

39 Chang AA, Morse LS, Handa JT, Morales RB, Tucker R, Hjelmeland L, Yannuzzi LA: Histologic localization of indocyanine green dye in aging primate and human ocular tissues with clinical angiographic correlation. Ophthalmology 1998;105:1060-1068.

40 Chang AA, Zhu M, Billson FA, Kumar NL, Beaumont PE: Indocyanine green localisation in surgically excised choroidal neovascular membrane in age related macular degeneration. Br J Ophthalmol 2004;88:307309. 